\title{
Nâzım Hikmet'in Ferhad ile Şirin Oyununda Mimetik Arzu ve Kısır Döngü
}

\author{
Dr. İbrahim GÜNGÖR \\ Dokuz Eylül Üniversitesi \\ GSE, Sahne Sanatları Ana Sanat Dalı (Mezun) \\ ibrahim.gungor99@gmail.com \\ ORCID: 0000-0003-3633-8524
}

\begin{abstract}
Öz
Bu çallşmada temel amaç Nâzım Hikmet'in Ferhad ile Şirin oyununun Rene Girard'ın kapsamlı bir teoremin başlangıç noktası olarak ortaya attığı 'mimetik arzu' kavramı çerçevesinde analiz edilmesidir. Girard, edebiyat kuramcısı olarak başladığı akademik çalışmalarına kültürün ve dinin kökenlerine eğildiği bir sentez ile devam etmiştir. Bu esnada da mitleri, kutsal kitapları, romanları ve hatta tiyatro metinlerini çözümlemeleri için sadece bir analiz malzemesi olarak değil aynı zamanda bir kanıt niteliğinde kullanmıştır. Köken olarak bir halk hikâyesine dayanan Ferhad ile Şirin oyunu da 'mimetik arzu'nun yoğun olarak görüldüğü bir ilişkiler ağına ve rekabetten şiddete uzanan bir çatışma ortamına sahiptir. Illk bakışta romantik görülebilecek yapısının derinlerinde yatan 'arzunun cehennemi mekanizmaları' analiz edildiğinde, oyunun Girard'ın 'romansal hakîkat' olarak ifade ettiği özellikleri pek çok noktada taşıdığı görülür. Ama oyun sonuna doğru kimi koşut düşünceler ortaya çıkmaya başlar. Bu noktalar Nâzım Hikmet'in toplumcu gerçekçi bakışının oyuna nüfuz etmiş izleri ile Girardyen bir düşüncenin karşı karşıya geldiği anlardır.
\end{abstract}

Anahtar Kelimeler: tiyatro, mimetik arzu, rene girard, nâzım hikmet, ferhad ile şirin.

Güngör, İ. (2021). Nâzım Hikmet'in Ferhad ile Şirin Oyununda Mimetik Arzu ve Kısır Döngü. ARTS: Artuklu Sanat ve Beşeri Bilimler Dergisi, 5, ss. 140-164. 


\title{
Mimetic Desire and the Vicious Circle in Nâzım Hikmet's Ferhad and Şirin
}

\begin{abstract}
This study aims to analyse the play Ferhad and Sirin by Nâzım Hikmet within the framework of the concept 'mimetic desire' put forward by Rene Girard as a terminus a quo to a comprehensive theory. Girard synthesises the academic work he begins in literary criticism with the origins of culture and religion. In the process he uses myths, religious texts, novels and plays not only as material to be analysed and deciphered but also as evidence. The play Ferhad and Sirin which originates from a folk story yields an environment of conflict in which a dense case of 'mimetic desire' is seen in the cobweb of relationships sprawling from rivalry to violence. When the "infernal mechanism of mimetic desire" is analysed underlying what seems at first a romantic structure, the play can be seen to carry at various points what Girard defines as 'romanesque truth'. However, towards the end of the play some parallel thoughts begin to emerge. These points are where Nâzım Hikmet's social realist point of view penetrating the text meet Girardian thought.
\end{abstract}

Keywords: theatre, mimetic desire, rene girard, nâzim hikmet, ferhad and sirin. 


\section{arts}

\section{GíRiş}

Rene Girard bir edebiyat kuramcısı olarak başladığı araştırmacılığının ilerleyen dönemlerinde antropoloji, kültür ve dinler tarihi gibi alanlara ilgi duymaya başlamıştır. Girard, 'şiddet' ve 'kutsal' arasındaki ilişkiyi görüşlerinin temeline yerleştirmiş ve 'mimetik teori'sini yaratmıştır. Bu teorinin temel önermesi 'arzu'nun mimetik bir doğaya sahip olduğudur. 'Arzu' temelde mimetiktir, yani taklide dayanır. Bu düşüncesini ilk çalışmalarında edebî eserleri incelerken geliştirmeye başlamış, sonra kültürün ve dinin kökenine dair kapsayıcı bir teorem olarak Şiddet ve Kutsal (1972) isimli çalışmasında açıklamış, daha sonra gelen eleştirilerin de bir söyleşi dilinde yanıtlandığı Dünyanın Kuruluşundan Beri Gizli Kalmış Sırlar (1978) 'da detaylandırmış ve farklı bir boyutunu da Günah Keçisi (1982) isimli kitabında ele almıştır. Düşüncelerinin bilimsel bir dayanak kazanması için mitleri, efsâneleri, kutsal kitapları kanıt olarak ele aldığı gibi romanları ve tiyatro metinlerini de benzer bir bakışla analiz etmiştir. Girard kurucu bir öge olarak 'şiddet' ve 'kutsal' ilişkisini incelerken edebî eserleri o derede bir kanıt niteliğinde sunar ki edebiyata estetik ya da etik değeri kadar, hatta onlardan da çok epistemolojik değer atfettiği düşünülür (Fleming, 2014, s. 2).

Illk çalışmalarında Cervantes, Stendhal, Flaubert, Dostoyevski, Proust gibi isimlerin romanlarına eğilen Girard, sonrasında Shakespeare' in oyunlarını incelemiştir. Shakespeare'in "ender bulunan ve radikal bir sezgi" (2018, s. 57) gösterdiğini söylemiş ve başlı başına Shakespeare oyunlarını ele aldığı Theatre of Envy: William Shakespeare (1991) isimli çalışmasını yazmıştır. Bu kitapta başka oyunlar ile birlikte özellikle Bir Yaz Gecesi Rüyası oyununu Shakespeareyen mimetik teorinin kusursuz bir örneği olarak enine boyuna analiz etmiştir (Girard, 1991, s. 46). Girard, Shakespeare' in oyununa teoremi açısından yoğun ilgi duymuş ve şöyle demiştir: "Şiddetli ve kolektif mimesis hadiseleri hakkında, Bir Yaz Gecesi Rüyası' ndan daha belirleyici olanı yoktur herhalde (...)" $(2018$, s. 57).

Rene Girard'ın 'mimetik arzu' yaklaşımı göz önüne alındığında Nâzım Hikmet'in yaygın olarak Ferhad ile Şirin olarak bilinen ama tam adıyla Ferhad, Şirin, Mehmene Banu ve Demirdağ Pınarının Suyu isimli oyunu (bundan sonra Ferhad ile Şirin olarak bahsedilecektir) da yoğun bir mimetik ilişki ağı (rekabet ağı) barındırmaktadır. Çalışmada bu iddianın detaylı olarak ortaya koyulabilmesi için 
önce Girard'ın 'mimetik arzu' kavramı ayrıntılarıyla ele alınacak, sonra Ferhad ile Şirin halk hikâyesinin kökenlerine ve Nâzım Hikmet'in Ferhad ile Şirin oyununun konusuna göz atılacak daha sonra da 'mimetik arzu' perspektifinden metnin okunmasına geçilecektir.

\section{Mimetik Arzu}

Yeryüzündeki şiddet döngüsü pek çok farklı dönemde farklı incelemelere konu olmuştur. İnsanların şiddete olan yatkınlığı ya da başka bir ifade ile eğilimi hep bir sorunsal olarak işlenir. Rene Girard kapsayıcı teoremi ile bu sorunun kökenine ya da içkinliğine ilişkin cevaplar bulmaya çalışır. Girard'a göre dinler ve kültürler kendilerini kurmak ve sürdürmek için şiddeti gizlemek zorundadır (2005, s. 131). Bu giz ancak mimetik olanın perspektifinden bakıldığında açığa çıkarılabilecektir.

Mimetik olanın incelenmesi Platon-Aristoteles çizgisinden bu yana sosyal bilimler ya da sanat araştırmalarında önemli bir yer tutmaktadır. Rene Girard mimetik olana atfedilen olumsuz görüşlerin karşısına bir kurucu öge tasarımı ile çıkmıştır. Mimetik olanın 'sürü'ye ya da 'kullaşma'ya, 'tektipleşme'ye dönük bir potansiyel taşıdığına duyulan inancın Platon'a dayanan bir gelenekten kaynaklandığını söyler. Girard'a göre "taklit kültürel sorunsalını kesin hâliyle Platon belirlemiştir" (2018, s. 20). Ama Girard, Platon'un mimetik olana bakışında asıl unsurlardan birinin budandığını düşünmektedir. Ona göre "insan tavırlarında öğrenilmemiş hiçbir şey, ya da hemen hemen hiçbir şey yoktur ve her öğrenme süreci taklite indirgenebilir. Eğer insanlar birdenbire taklit etmeye son verseler, tüm kültürel biçimler ortadan kalkardı" (2018, s. 18-19). Yani Girard'da taklit, üzerine özellikle çağdaş dönemde yapılmış olumsuz atıflara karşı† bir şekilde, kültürel biçimlerin kurucu olgusudur (Girard, 2013, s. 1819). Ama mimesisi ne Aristoteles'in anladığı anlamda pozitif bir öykünme hâli ne de Platoncu bir anlamda tek başına yıkıcı bir öge olarak görmez. 'Ben' ve 'Öteki' arasındaki daimi karşılıklıı̆̆ı vurgular şekilde bir mimetik ilişki tanımlar. Bu karşııklı̆ğı yaratan öge 'mimetik arzu' dur, yani arzunun mimetik doğasıdır.

Girard, 'mimetik arzu'yu yeryüzündeki şiddet döngüsünün köken olgusu olarak görür. 'Mimetik arzu' kavramı, ilkel düzeyde bir 'arzu üçgeni'nin işlemesi ile ortaya çıkar: 'Arzu üçgeni', Özne-model-nesne arasında oluşan ilişki biçimidir. Temel olarak 'mimetik arzu' nun oluşumunu sağlayan mekanizma budur. Girard, öznenin nesneye 
karşı duyduğu arzunun model tarafından dolayımlandığını iddia eder. Yani arzu önsel olarak nesnede tanımlanmaz. Bizim nesneye yönelmemizi sağlayan, arzuyu besleyen şey nesnenin 'ne'liği ya da ona duyulan ihtiyaçtan çok onun başka birisi tarafından arzulanıyor oluşudur (Girard, 2013, s. 206). Gil Bailie, Violence Unveiled: Humanity At The Crossroads (Gözler Önüne Serilen Şiddet: Dönüm Noktasındaki insanlık) isimli çalışmasında bu durumu şöyle örnekler:

Şöyle bir sahne hayal edin. Küçük bir çocuk kreşte kendisi için etrafa saçılmış düzinelerce oyuncağın arasında yalnız başına oturuyordur. Orada dalgın bir şekilde oturmuş sıradan bir ilgi ile hoşuna gidebilecek herhangi bir oyuncak için bakınmaktadır. İçeriye başka bir çocuk girer ve odaya bakınır. Diğer çocuğu ve çevresindeki düzinelerce oyuncağı görür. Sonra ikinci çocuğun oyuncakların arasından birini seçme zamanı gelir. En çok ilgi çekici bulacağı oyuncak hangisi olacaktır? Büyük intimalle ilk çocuğun sıradan bir bakışla da olsa ilgileniyor göründüğü oyuncak. İkinci çocuk herhangi bir oyuncaktansa birinci çocukla daha çok ilgileniyormuş gibi gözükür, ama bu ilgi ilk çocuğun ilgi gösterdiği oyuncağa yönelik bir meraka çevrilir... Peki ya ikinci çocuk oyuncak için harekete geçerse ne olur? Birinçi çocuğun umursamazlığı bir anda yok olur. Aniden can havliyle oyuncağa sarlir. Son derece hiddetli bir şekilde "O benim" der. Onun bu yoğun tepkisi ikinci çocukta oyuncağa dönük en baştaki yumuşak harekete geçişinin sahip olduğundan çok daha güçlü bir arzu doğurur. i̇ki çocuk birbirlerine ne kadar çok beğendiklerini kanıtlamaya çalışarak oyuncağa yönelik arzularını beslerler. Çatışma çözümsüz kaldıkça, iki çocuğun da bu kavgada biraz sorumluluk alması önerisi kararlı bir şekilde reddedilecektir. Her ikisi de bu anlaşmazlığın sorumlusunun diğeri olduğundan emin olacaktır (Bailie, 1995, s. 116-117).

Bu temel rekabet arzunun derecesini de belirler. Her iki taraf da nesneye sahip olabilmek için ona ne kadar ihtiyacı olduğu, nesnenin onun için ne kadar hayati, vazgeçilmez ve devredilemez olduğu ile ilgili varsayımlarını güçlendireceklerdir. Bu durum karşılıklı bir taklit etkisi yaratır. Nesneye ilk yönelen kişi taklitçisi tarafından engellenmeye çalışlır. Ama kısa süre içinde bu rekabet, model-özne ilişkisinin de birbiri içinde erimesine neden olur. Karşılıklı rekabet ile şiddete doğru ilerleyen çatışmalarında birbirinin taklitçisi olmaya başlarlar. Girard bu taklit durumunun özünde, arzunun özelliğinin yattığı sonucuna varır: "Arzu temelde taklit eder [mimetiktir], örnek aldığı arzuya göre biçimlenir ve örneğin seçtiği nesneyi seçer" (2003, s. 206-207).

Ama bu noktada rekabeti/çatışmayı doğuran bir eşik göze çarpmaktadır. Düşüncelere yönelik taklide duyulan ilk arzu zararsız görülür. Ama taklit ideallere/ hedeflere yöneldiği anda kişi bir tehdit, rakip olarak görülmeye başlanı; rekabet ve şiddet ortaya çıkar. Kişinin temel gereksinimleri giderildiği anda ilk arzusu 'kendisi olmak' ya da temelde 'olmak'tır; özgün ve biricik varlığını hayatta görünür kılmak istemektedir. Bu hedefinin yöneleceği nesnenin ne olduğunu bilmediği için "önceden 
bu 'olmak'la donatılmış olduğu anlaşılan örnek kişi bir nesneyi arzuluyorsa o nesne daha tam, daha doygun bir 'olmak' sağlayabilecek yetide" (Girard, 2003, s. 207) görülmeye başlanır. Mimetik arzu devreye girdiği andan itibaren kendi varoluşunu tehdit altında hisseden 'örnek/öteki', çatışmanın da yolunu açmış olur. Bu artık bir çeşit itibar (prestige) mücadelesidir. Girard çatışma ve bunun doğurduğu şiddet dizgesini şöyle açıklar:

\begin{abstract}
Rekabetler şiddetlendikçe, rakipler buna neden olan nesneleri unutmaya yöneldikçe, birbirlerinden büyülenmiş gibi etkilenmeleri artar. Rekabet tüm dışsal hesaplarından arınır ve özetle, katıksız rekabet veya itibar rekabeti halini alır. Her rakip diğeri için hayranlık duyulan ve nefret edilen, hem yere serilmesi hem de özümsenmesi gereken model-engel haline gelir (Girard, 2018, s. 43).
\end{abstract}

Model, engel hâline geldikçe bir yandan nesneden uzaklaşilır ama diğer yandan da 'nesne' gerçekte sahip olmadığı bir değer kazanır. Bu değer dolayımlayıcının itibarının nesneye yansımasıdır (Girard, 2003, s. 248; Girard, 2013, s. 35). Girard'a göre "üçgen arzu, nesnesinin yüzünü değiştiren arzudur" (2013, s. 35). Nesnenin kazandığı değer, ona herkes tarafından arzulanmasını sağlayacak biriciklik sağlar. Bu, rekabetin doğurduğu arzunun yarattığı bir yanılsamadır. Artık temel güdülenme nesneye sahip olma düzleminde değil, rakibin alt edilmesi düzleminde işlemeye başlar. Bu alt etme işlemi sonrası kazanımları önem kazanır. Nesneye sahip olma arzusunu yaratan 'öteki'nin ona sahip olma imkânı ya da ihtimali veya bu yöndeki girişimi, özneyi onun benzeri bir arzu ile donatır. 'Öteki/model' de bir rakibin ortaya çıkışı ile başka bir güdülenme yaşar. Artık 'nesne/hedef'e yönelik bir tehdit ile karşı karşıyadır. Onu elde edemezse onsuz kalacağı düşüncesi ile arzusunu güçlendirir. Ve rekabet içerisinde o da temel hedefi olan nesneden uzaklaşarak 'mimetik arzu' ile koşullanır. Bu oluşan 'arzu üçgeni' Girard'a göre ikizkenar bir üçgendir. Dolayısıyla dolayımlayıcı ve özne birbirine yaklaştıkça arzu da artar: "Kutsal nesne yaklaşmıştır; elin erişebileceği bir yerde gibidir; özneyle bu nesne arasında görünüşłe tek engel kalmıştır: dolayımlayıcının kendisi. Dolayımlayıcı yaklaştıkça eylem daha ateşli bir nitelik kazanır" (2013, s. 83) Girard bu yakınlaşma sonrası oluşan şiddetli rekabet hâlinin cinayete kadar uzanabileceğini söyler (2013, s. 83).

Girard'a göre mimetik arzuyu şu üç kavramdan ayırmak olanaksızdır: Özdeşleşme, nesne seçimi ve rekabet (2003, s. 254). Seçeneklerin yaratılmasından önce bir model/öteki ile özdeşleşme, onun yöneldiği nesneye (seçeneğe) yönelim ve ortaya çıkan 'mimetik arzu' ile başlayan karşılıklı rekabet. Nesneden rekabete 


\section{arts}

yaşanan birinci yanılsama sonrası ikinci yanılsama rekabetin kartopu etkisinde yaşanır. Nesnenin kazandığı sanal prestij ya da daha önce de söylendiği gibi biriciklik, etrafına daha fazla sayıda talebin toplanmasına neden olur. Bu kalabalıklaşma sonrası şiddet zamanla toplum ya da topluluk için bir tehdit noktasına gelir. Çünkü rekabetin çözümsüzlüğü noktasında ortada şiddetten başka seçenek kalmamıştır. Her bir özne ötekini hedefi yönünde engel ve haksız görür. Ortaya çıkan bu şiddet bir intikam kısır döngüsü yaratır. İntikam ise karşılıklı bir korku sonucu ortaya çıkar; ya 'öteki' beni saf dışı bırakırsa? Bu durum dolayımlayıcı üzerinde çifte bir rol yaratır. $\bigcirc$ hem nesneyi işaret eden 'kutsal' model hem de ona kavuşmayı engelleyen 'kötü' engeldir (Girard, 2013, s. 80).

Karşlıklı şiddet, farkllıkların yok olmasına ve tüm toplumun şiddetin tehdit eden bulaşıcı etkisi karşısında savunmasız kalmasına neden olmaktadır. Bu farksızlaşma durumu yıkıcı bir şiddet döngüsü doğurur. Kartopu etkisi ile her geçen an kalabalıklaşan rekabet, günah keçisinin ortaya çıkmasını zorunlu kılar. Aksi halde şiddet önü alınamaz bir şekilde yok oluşu getirmektedir. Şiddet ile kaosa sürüklenen topluluk, şiddetin sorumlusu olduğuna inandığı bir kişiyi kurban olarak seçer. Bu kurban bunalımının da sonu anlamına gelmektedir. Topluluğu yıkıma sürükleyen şiddeti doğuran rekabet ve çatışma hâli, insanların üzerine çökmüş bir lanet olarak görülür. Bu metafizik sıçrama en temelde yatan 'mimetik arzu'nun yarattığı rekabetin ve bu rekabetin ortaya çıkardığı karşılıklı şiddetin oybirliğine dayalı şiddet ile noktalanması ya da durdurulmasına yöneliktir.

Bu noktada oybirliğine dayalışid detüzerine birkaç sözetmemizgerekmektedir. Yıkıcı hâle gelen karşılıklı şiddet mekanizması ancak bir suçlunun bulunması, kurban edilmesi ya da sürgüne gönderilmesi sonrası oluşan oybirliği ya da anlaşma ile noktalanır (Bkz. Girard, 2013, s. 110-123). Bu mekanizma şiddetin bir günah keçisine yansıtılarak toplumun ya da topluluğun şiddetten arındırıması amacını taşır. Bu kez şiddet yıkıcı değil yapıcı bir neden ile kullanılmaktadır. Bu nedenle bu tür şiddete 'oybirliğine dayalı şiddet' ya da 'kurucu şiddet' denilmektedir. Buradaki şiddet koruyucu bir mekanizma olarak algılanmaktadır.

Girard'ın teoremi kimi yan yana gelmez denilen sözcükleri bir araya getirmeyi de bu temelüzerinde başarır. Şiddet modern düşüncenin tek yanlı bakışından kurtarılıp 
çift tarafı bir kavrama dönüştürülür. Yani ortaya çıkışı yok edici ve kaotik olabildiği kadar kurucu ve düzenleyici de olabilir. Girard, "suçlu ve yasadışı bir şiddetin içkinliği karşısında, kutsal, yasal ve meşru şiddetin etkili aşkınlığı"nı $(2003$, s. 32) görür. Bu aşkınlık onun mitolojik, ayinsel ve dinsel yansıması ile ilintilidir. "Sistemin önleyici ve tedavi edici olması intikamın süreğenlikten çıkarıması için aşkınlık gerekir, böylece intikam kısır döngüsü kurulmaz" (2003, s. 32). Temelde yatan mekanizmanın unutulması ve mitsel, ayinsel bir düzen inşa edilmesi insanın kendinden kaynaklı şiddet düzenini, kendinden saklayan kutsallaştırmanın bir parçasıdır. Ama bu bilmezlik toplumlar ve topluluklar için şiddeti önleyici bir fren işlevi görmektedir (2003, s. 193, 227).

Bu noktada ortaya çıkan ikileşme ise bugün teolojik düzlemde ele alınan ve metafizik sorunsallar olarak görülen dinsel ve ayinsel görüşlerin yaşamsal kökenine ilişkindir. Girard'ın düşüncesinde şiddetin önleyici olabilmesi için uygulanan kurban mekanizmasının taşıdığı aşkınlık, bugün pek çok modern incelemecinin görmezden geldiği bir düşünceye dayanmaktadır. Kutsal ve şiddet yan yana ve aynı hedefe hizmet etmek için bulunmaktadırlar.

Girard'ın 'mimetik arzu' kavramı şiddeti, karşılıklı ve oybirliğine dayanan şiddeti ortaya çıkaran domino taşıdır. Bu etki daha sonra ortaya kutsal olanı ve şiddetin çözümü olan mekanizmayı çıkaracaktır. İntikam döngüsünün sonlanması için kurban bunalımı çözülmelidir. Bu da ancak bir aşkınlaştırma, bir yansıtma işlemi ile gerçekleştirilir. Kurban olarak bir kölenin, bir hayvanın seçilmesi, intikam kısır döngüsünün kırılmasına ve şiddetin aşkın bir varlığın ya da varsayımın ürünü olması sağlanarak toplum dışına atılmasına olanak sağlar. ìkame kurban ismi verilen bu mekanizma aslında günümüzde bulduğu karşılıkla günahı değil topluluktaki kişilerin birbirine karşı beslediği düşmanlığı bünyesinde toplamıştır. Ayinin etkisi tedavi edici değil önleyicidir. Yok olması ile günahlar silinmez, şiddetin topyekûn yok ediciliği önlenmiş olur (Girard, 2003, s. 139-142). Bu durum farksızlığın sonlandırıması ve toplumun yine heterojen bir birlik olması anlamını taşır. Girard'a göre: "(...) kültürel düzen, düzenlenmiş bir farklılıklar sisteminden başka bir şey değildir. Bireylere 'kimlik'lerini veren, kendilerini başkalarına göre konumlandırmalarını sağlayan bu farklııklardır" (2003, s. 67). Girard düşsmanlığı çığııından çıkaranın farklılıkların yitirilmesi olduğunu düşünür. İnsan adaletinin temeli farklılık düzeninin korunabilmesinde yatmaktadır. Bu düzen bozulduğu anda adalet de yerinde duramaz (2003, s. 68-71). 


\section{arts $=$}

Bu anlatılanlar temel oybirliğine dayalı şiddet mekanizmasının ana özelliklerini taşımaktadır. Kutsal ile şiddet burada da yan yanadır. İkame kurban toplumu yıkımdan kurtarmıştır; önce bütün laneti bünyesinde toplamış ve topluluğu arındırmış, arınma sonrasında ise kendisi bir kurtarıcıya dönüşmüştür. Ayinleşen kurban törenlerinin işlevi, "şiddeti 'temizlemek', yani onv 'aldatarak', intikamının alınması tehlikesi bulunmayan kurbanlara yönelterek basıncını almaktır" (Girard, 2003, s. 49). Yani dinsel yan aslında şiddete bağımlıdır ve koruyucu bir aşkınlaştırma işlevidir.

Aşkınlaştırılarak temeldeki rekabet ilişkisini durdurmak ve toplumsal bir yıkıma götüren 'şiddet'in yolunu kesmek, 'şiddet'in dünya dışı bir önleyici, tedavi edicigücün parçası olarak görünmesine neden olur. Eğer bu yapılmazsa 'mimetik arzu'nun neden olduğu her rekabette taraflar 'şiddet'i kendi şahsında canlandırarak egemen olmak, tanrısal şiddete hakim olmak ve gücü ele geçirmek isteğine yöneleceklerdir. Ama oybirliğine dayalı şiddet mekanizması tanrıyı topluluğun dışında tutar, kişilerin gücü elde tutmak için şiddete yönelmelerine engel olur: "Şiddet bir kez dışarı atııp tüm insanlardan kesin bir biçimde uzaklaştı mı, tanrılı̆ın aşkınlık dışında gerçekliği yoktur. İsterik bir rekabetin doğruca tanrısallık doğurması olanaksızdır. Tanrı, oybirliğine dayalı şiddet aracıı̆̆ıyla oluşmaktadır" (Girard, 2003, s. 204).

Rene Girard bu mekanizmanın uzantılarını çağdaş bilim adamlarının araştırmalarında göremez ve bu sezginin Sophokles gibi, Shakespeare gibi büyük yazarların eserlerinde ise yakalanmış olduğunu düşünür. Romantik Yalan ve Romansal Hakikat (2013) isimli eserinde çeşitli romanlarda bu ilişkinin izlerini sürer. Girard'ın bu çalışmasında pek çok örneğini verdiği üzere 'romantik yalan' arzunun kendiliğinden olduğunu ve özerk bir öznelliği savunur: "Romantikler imgelemin 'kendi kendini döllediğini' savunurlar" (2013, s. 35). Girard'a göre bu bir çeşit yanılsamadır ve bu fikrin karşısına 'romansal hakikat' düşüncesini koyar. Büyük yazarların eserlerinde sezgisel olarak hissedilmiş arzunun mimetik örneklerini bu hakikatin çeşitli görüngüleri olarak ortaya koyar. Ve arzunun kendiliğinden oluşu ile ilgili yönelimleri de, mimetik ilişkide arzulayan öznenin, arzusunun 'rakip/öteki'den 'bağımsız', 'kendiliğinden', 'özgün' olduğuna inandırma çabasının bir parçası olarak görür (2013, s. 55). 


\section{arts $=$}

\section{Ferhad ile Şirin Hikâyesinin Kökeni}

Hikâyenin ilk izlerine M. S. 6. yüzyıl civarında rastlanır. Sasani hükümdarlarından Hüsrev Perviz'in (M. S. 596-628) hayatı ve aşk maceralarının anlatıdığı hikâyelerde Şirin' den birkaç satırla söz edildiği bilinmektedir (Timurtaş, 1959, s. 65). Hikâye daha sonra 11. yüzyılda Firdevsi'nin yazdığı Şehname'de yer alır. Yine 11. yüzyılda Senai, 12. yüzyılda da Nizami, Hüsrev ü Şirin ve Şirin ve Hüsrev isimleriyle mesnevî tarzında konuyu işlemişlerdir. Hikâyenin İran'dan Türk kaynaklarına geçişi de Nizami'nin etkisi ile olmuştur ve Nevai, Ferhad u Şirin'i yazmıştır (Seyidoğlu, 2002, s. 133). Bu artık klasikleşmiş aşk hikâyesi operetlerde, operalarda, filmlerde ve tiyatro oyunlarında kullanılmış, Türk halk edebiyatına ve hayal perdesine konu olmuştur (Timurtaş, 1959, S. 69).

\section{Nâzım Hikmet'in Ferhad ile Şirin'i}

Nâzım Hikmet, Ferhad ile Şirin oyununu halk hikâyesinden yola çıkarak, kendi özgün şiirselliğiyle ve toplumcu gerçekçi bakışından ögeler katarak yazmıştır. Nâzım Hikmet'in 1948 yılında Bursa Cezaevi'nde yatarken kaleme aldığı oyunun konusu şöyledir: Arzen hükümdarı Mehmene Banu'nun kız kardeşi Şirin hasta yatmaktadır. Hastalığına uzun süredir bir çözüm bulunamamaktadır. Ülkeye onu iyileştirenin ödüllendirileceği ile ilgili haberciler salınmıştır. Saraya bir yabancı (GELEN) gelir ve Şirin'i iyi edeceğini söyler. Herkesin içinden gelen sesleri duyabilen bu çirkin yabancının bazı şartları vardır. Saray hizmetlilerinin iç seslerinde dillendirdikleri isteklerini şartları arasına koyar, iyileştikten sonra Şirin'e bir köşk yaptırımasını ister. En önemli şartı, Mehmene Banu'nun kardeşinin iyileşmesi için güzelliğini vermesi gerektiğidir. Mehmene Banu bu istekleri kabul eder ve Gelen'in büyüsü ile güzelliğini verip kardeşinin iyileşmesini sağlar.

Şirin için yapılan köşkün nakkaşlığını Ferhad yapmaktadır. Ferhad'ın bu işteki ustalığı dillere destandır. Ustabaşı, Şerif ve babası Behzad bile onu kıskanmaktadır. Ferhad dört gün dört gece uyumadan çalıştıktan sonra nakışlarını bitirip iskele üstünde uyuyakalır. O uyandığı zaman Mehmene Banu, Şirin ve saray eşrafı da biten köşkü görmeye gelirler. Şirin ve Mehmene Banu bu ziyareł sırasında Ferhad'ı görürler ve âşık olurlar. Şirin ziyaretten sonra Ferhad'ın yanına gider. Ferhad da Şirin'e âşık olur. 


\section{arts $=$}

Şirin ve Ferhad'ın kaçma kararına Dadı ve oğlu Şerif yardım ederler. Şerif, Ferhad'dan nakış ve boya sırlarını öğrenmek vaadiyle bu yardımı yapmaktadır. Kaçtıklarını duyan Mehmene Banu peşlerine adamlar salar. Yakalandıklarında Ferhad'a Demirdağ'ı delme cezası verir.

Arada 10 yıl geçer. Ferhad bu süre içerisinde aralıksız dağı delmek için çalışır, bir gün bile Şirin'in yüzünü göremez. Tüm bu çabası ile kasabada adı duyulmuştur. İnsanlar onu görmeye gelmektedir. Mehmene Banu, Şirin'e Ferhad'ın cezasının bittiğini, eğer hemen işi bırakırsa evlenmelerine izin vereceğini söyler. Fakat Ferhad artık dağı sadece Şirin'e kavuşmak için değil aynı zamanda kasaba suya kavuşsun diye delmektedir. Şirin'e işini bırakamayacağını ancak dağı delme işi bittikten sonra ona kavuşabileceğini söyler. Oyun Ferhad'ın gürz sesleri ile sona erer.

\section{Ferhad ile Şirin Oyununda Mimetik Arzu}

Girard'ın krizin ve kıyıcı şiddetin ortaya çıktığı dönemlerin genel özelliği olarak gördüğü veba, salgın, kuraklık, sel, açlık gibi dış nedenlerin veya politik ya da dinsel çatışma gibi iç nedenlerin (Girard, 2005, s. 17-18) pek çoğuna Ferhad ile Şirin oyununun genel yapısında rastlanmaktadır. Ferhad ile Şirin' de oyunun başında öğreniriz ki Arzen şehrinde uzun zamandır devam eden bir salgın vardır ve bu salgın temiz suyun olmamasından yani bir çeşit kuraklıktan kaynaklanmaktadır. Üstelik Sultan Mehmene Banu bu susuzluğa duyarsız kalmaktadır. Yani oyunda susuzluktan ve hastalıktan kırılan halk ile sarayın umursamazlığı arasında politik bir çatışma göze çarpar.

Dışarıdan Şirin'i iyileştireceğini söyleyerek saraya gelen yabancı (GELEN) şehrin durumunu da oyunda ilk dillendiren kişidir. "GELEN: Biliyorum. Arzen şehrinde içilecek su yok. Çeşmeleri su değil, irin akıtıyor" (Hikmet, 1987, s. 71). Şehrin içinde bulunduğu kriz durumu, Mehmene Banu'nun günah keçisi basmakalıplarına (bkz. Girard, 2005, s. 35, 39) uygunluğu ve GELEN tarafından gerçekleştirilen ayin ilk bakışta şehrin oybirliğine dayalı şiddetinin gerçekleşeceği ve Mehmene Banu'nun kurban edilerek şiddet döngüsüne bir son verileceği izlenimi yaratır. Mehmene Banu pek çok açıdan Girard'ın tarif ettiği günah keçisi özelliklerini taşımaktadır. Hem hükümdardır hem de dillere destan bir güzelliği vardır. Girard günah keçisinin yani ikame kurban olarak seçilen kişinin Pharmakos gibi toplum dışı köleler olabileceği gibi Kral (hükümdar) da 
olabileceğini söyler. Çünkü Kral da toplum dışı, kesim dışıdır. Onu yalıtlayan merkezî konumudur. Pharmakos toplumun altındaysa kral da üstündedir (Girard, 2003, s. 1617).

Üstelik Girard'ın ilkel kabilelerde bulguladığı ayinlerdeki kralın ikili dokusu burada da görülmektedir. Mehmene Banu hem kurban gibidir hem de hükümdar olarak ayinde (büyüde) hâlâ tek söz sahibidir. Kararı veren o'dur. GELEN tarafından yapılan tören de hem belirli bir kurban edimini talep etmekte (güzelliğin fedası) hem de Girard'ın bahsettiği tüm kirlerin, kötülüklerin içinde atıldığı yani arınmayı ifade eden ateş ögesini (Bkz. Girard, 2003, s. 156-157) içermektedir. GELEN, Şirin'in iyi edilmesi karşılığında ateşi yakarak büyüyü yapar. Ateş söndüğünde büyü bitmiş, Şirin uyanmış, Mehmene Banu'nun güzelliği kurban edilmiştir. Ama tüm bunlara rağmen tören şiddetin toplum dışına yansılanmasını sağlayacak temel ögeleri içermez. Çünkü GELEN Arzen şehrinden değildir ve temelde ikame kurban için bir oybirliğine dayanmamaktadır. Girard oybirliğinin önemini şöyle ifade eder: "Oybirliği kesin bir zorunluluktur. Tek bir katılımcının çekimser kalması bile kurban edimini yararsızdan da öte, tehlikeli kılmaktadır" (Girard, 2003: 141). Bu nedenle kurucu şiddet gerçekleşmemiştir. Dahası, bu tören oyun boyunca sürecek 'mimerik rekabet' ağının da başlatıcısı olacaktır.

Feda edilen güzellik sadece Şirin'i kurtarır; oysa kentte hâlâ susuzluk devam etmektedir. Gelen dilekleri içinde şehrin susuzluktan kurtarılmasını iletmemiştir. Bunun başarılamadığını, uzun zamandır denendiğini dillendirmiştir. Pek çok noktada Girard'ın sözleri ile söylersek "arzunun cehennemi mekanizmaları" (2013, s. 80) işlemeye devam etmektedir. Bunun yaratacağı farksızlaşma şiddetin toplum dışına atılmasını sağlayacak bir oybirliğini bir türlü doğuramamaktadır. Mehmene Banu kıyım basma kalıplarını taşısa da bu nokłada dikkat çekenin intikam kısır döngüsünün devamı olduğunu söylemek daha yerinde olacaktır.

Başka bir açıdan bakıldığında GELEN, bir ikame kurban gibi gözüken Şirin'i kurtarmış ve şehirdeki kaosun asıl sorumlusu olarak görülebilecek Mehmene Banu'ya bir günah keçisi basmakalıbı daha eklemiştir. Artık Mehmene Banu güzel ve çirkini, iyi ve kötüyü, kutsal ile lanetliyi aynı bedende taşımaya başlar. Aynı zamanda sorunları çözmeyen ama iktidarda kalmaya devam eden bir güçsüzdür. 


\section{$\operatorname{arts}=$}

Şehirdeki susuzluk bir tür salgına sebep olmuştur ve son verilmesi gerekmektedir. Yani şiddetin topluluk dışına atılması sağlanmalıdır. Hükümdar olarak Mehmene Banu'nun bu reel soruna bir çözüm üretmediği ortadadır. GELEN'in burada intikamın devamını sağlayan bir temsilci olduğunu söylemek mümkündür. Mehmene Banu'dan güzelliğini alarak ona onun şiddetini geri yansıtmaktadır. Toplumdaki kaos devam etmekte, Mehmene Banu halka suyu ulaştırmayarak intikam döngüsünün sürmesine neden olmaktadır. Bu içselleştirilmişşiddet ve yıkım Mehmene Banu'nun ikame kurban değil şiddetin taraflarından olan rakiplerden biri olmasını sağlar. Kurucu şiddet oyun boyunca iç içe geçen pek çok hikâyedeki mimetik rekabetlerle bir türlü sağlanamamaktadır.

Mehmene Banu güzelliğini feda ettiği andan itibaren metafizik bir arzu olarak kaybolan güzelliği ile ilgili bir arayışa girer. Bu güzellik, sürekli yanında yer alan ve onun için vazgeçtiği güzelliği ona hatırlatan Şirin'in vücudunda yaşamakta ve Şirin bir çeşit soyut arzunun modeli olarak Mehmene Banu'yu arzu ile donatmaktadır. Fakat bu metafizik arzu bir model olarak Şirin, Mehmene Banu'ya Ferhad'ı işaret edene kadar rekabete dönüşmemiştir. Oyunun şiddet kısır döngüsünde önemli bir yer tutan arzu üçgeni bu olayla başlayacaktır.

Oyunun merkezinde yer alan bu 'aşk üçgeni', rekabet ilişkisinin çok farklı şekillerde görünür olduğu bir yapıdadır. Mehmene Banu ve Şirin oyunun 3. sahnesinde aynı anda Ferhad'ı görmüşlerdir. Bu sahnede Şirin ve Mehmene Banu'nun iç seslerini duyarız. Bu sesler bize ikisinin de Ferhad'a âşık olduklarını gösterir (Hikmet, 1987, s. 89). Şirin ve Mehmene Banu'nun birbirlerinin Ferhad'a duyduğu ilgiyi ilk an fark edip etmedikleri ile ilgili oyunda bir vurgu yoktur. Mehmene Banu nakışlarına bakmamış olmasına rağmen Ferhad'ı sarayın baş nakkaşı yapmıştır (Hikmet, 1987, s. 89). Bu vurgunun Şirin'in ilk anda duyduğu arzunun kuvvetlenmesine neden olmuş olabileceğini düşünmek mümkündür. Ama henüz model-engel ilişkisi belirgin değildir. Sahnenin devamında herkes çıktıktan sonra Şirin, Ferhad'ın yanına gider ve bu üçlü ilişkide arzu nesnesi Ferhad'a doğru ilk adımı atar. Ve Ferhad ile Şirin'in hikâyesi ile beraber rekabeti ve şiddeti doğuracak kısır döngü başlamış olur.

Başlangıçta model-engel ilişkisi belirgin olmasa da Mehmene Banu'nun da Şirin'in de aynı hedefe yöneldikleri açıktır. Ve çalışmanın başında çocuklar üzerinden 
verilen örnekte görüldüğü gibi kişilerden biri nesneye doğru adım attığında diğerinin onv elde etme isteği de bir anda kamçılanmaktadır. Bu noktada tek fark Girard'ın da belirttiği $(2018$, s. 21) yetişkinlerin çocuklardan farklı olarak 'arzu'yu bastırmayı/ gizlemeyi öğrenmelerinden kaynaklanır. Ferhad'la Şirin'in kaçtıklarını öğrenen Mehmene Banu'nun artık bu durumu bir rekabet olarak algılamaya başladığı ve arzusunun şiddete dönük bir yöne girdiği görülür. Şimdi o Şirin'in işaret ettiği Ferhad'a başka bir ilgi duymaya başlamış ve kardeşini de bu ilişkide engel olarak konumlamıştır. Bunu Mehmene Banu'nun repliklerinde açıkça görmek mümkündür: "Yarabbi, nasıl seviyorum. Hele şimdi, hele şimdi... Hiçbir ümit yokken artık... Belki hiçbir ümit olmadığı için... (...) Nasıl kıskanıyorum... Gebereceğim... (...) Şirin'im, bir tanem, kardeşim, öldüreceğim seni..." (Hikmet, 1987 s. 104). Bu rekabet ilişkisi onda, Ferhad'a karşı daha önce olmadığı kadar yoğun bir ilgi yaratır; fakat sözlerinin devamından da anlaşılacağı üzere bu ilginin kaynağı Şirin'dir ve önemli olan Ferhad'ı elde etmesi değil Şirin'i alt etmesidir. Oyun boyu Ferhad'a ulaşmaya hiçbir zaman çalışmaz, sadece Şirin'in ona ulaşmasını engellemeye çalışır.

Dadı, Mehmene Banu'ya başka olasılıklardan, zenginliğinden, hükümdar oluşundan, vücudunun güzelliğinden dolayı elde edebileceklerinden söz eder (Hikmet, 1987, s. 108). Ama Mehmene Banu 'mimetik arzu' ile koşullanmıştır. Ve Şirin'i alt etmek isteği ile donanmıştır. Ortaya çıkan rekabet ilişkisi tüm diğer olasılıkların reddini getirdiği gibi şiddete doğru olan gidişi de besler. Mehmene Banu, Dadı'nın verdiği örnek üzerine 'mimetik arzu'sunun temeline iner. Şirin'in, Ferhad tarafından beğenilmişolmasıüzerine onunla benzerlikleriüzerinde durur. Kendisinin hâlâ beğenilip beğenilemeyeceğini sorar (Hikmet, 1987, s. 108). Onu sevecek birinin arayışı değildir bu. Beğenilmenin, tercih edilmenin arayışıdır. Şirin, Mehmene Banu'nun uğruna feda ettiği güzelliğinin daimî taşıyıcısı olarak hem rakibi hem modeli olmuştur.

Bu durum, Girard'ın bahsettiği nesneyi elde edememiş olmanın yarattığı başarısızlık ve sonrasında ortaya çıkan iktidarsızlık hissini (Girard, 2013, s. 32) Mehmene Banu'da da yaratır. Mehmene Banu bir sultan olarak Dadı'nın da söylediği üzre hem makamı hem de güzel vücudu sayesinde kolaylıkla Ferhad gibi birini veya daha iyisini elde edebilecekken Şirin'in dolayımlayıcılığı onu bundan alıkoyar. Şirin ve Ferhad'ın yakalanıp getirilmesinden sonra Şirin'in söyledikleri ve sonrasında geçen zamanda yanında oluşu Mehmene Banu' da bahsi geçen iktidarsızlığı ve inadı yaratır. 11 sene 


\section{arts}

boyunca devam edecek bu durum onun da yıkımını getirir.

Oyunda belirgin olan bu rekabet ilişkisinin bir başka özelliği bu durumun içselleştirilmesinin yaygınlığıdır. Mehmene Banu'ya karşılıksız bir aşk besleyen Vezir, onun Ferhad' a olan aşkındaki model yansımasını fark etmiştir ve ona aslında yapması gerekeni işaret ederken tam da 'mimetik arzu'nun farkında olarak konuşmaktadır. Vezir şöyle der: " (...) Kaybettiğini kazanmaya cesaret edemeyecek kadar korkaksın. Onu senden alanı ezemeyecek kadar rahatına düşkünsün..." (Hikmet, 1987, s. 102).

Dadının başka olasılıklara Vezir'in ise şiddete dönük önerilerini reddeden Mehmene Banu, Ferhad'ı dağı delmeye göndererek arzu nesnesini uzaklaştıır. Modeli ile yan yana kalmayı sürdürür. Gittikçe iktidarsızlaşan bir iktidar temsilcisi olarak kardeşi Şirin'i bir yandan 'kötü' engel olarak görmekte ve onu öldürmek istemekte iken diğer yandan bir model-tanrı haline gelen Şirin'e dokunmamaktadır. Çünkü ancak bu yolla nesneye dönük arzusu sürekli olarak canlı kalacaktır. Şirin aynı zamanda Mehmene Banu'nun feda ettiği güzelliğinin taşıyıcısı olarak da bir 'çifte model-tanrı' olarak yakında tutulmalıdır.

Mehmene Banu'nun Ferhad'a dönük arzusu 'bastırılan', gizli tutulan bir arzudur. Yakalanan çiftin cezalandırımasında iki nokta Mehmene Banu'nun kararlarını etkiler görünmektedir. Şirin, aynı zamanda bir hükümdar olan ablasına ihanet etmiştir. Ferhad ise hükümdarın kardeşini kaçırarak bir anlamda düzeni bozmuş ve dahası askerleri ile de çatışmıştır. Ferhad'a uygulanacak şiddet bu merkezden gelecekmiş gibi görünür. Ama temelde Mehmene Banu'ya yön veren bu noktaların dışında kalan gizli tuttuğu arzusudur. Dolayısıyla Mehmene Banu, model-tanrısına da, arzu nesnesine de sahip olduğu iktidar gücü ile muamele yapamamakta bir anlamda onu ele geçirmiş mimetik rekabetin diliyle konuşarak elindeki gücü kullanamamaktadır. Sonuç olarak da 'mimetik arzu'nun yarattığı rekabet bir kısır döngü halinde sürmektedir.

Mehmene Banu 11 yll boyunca ne başka birine yönelir ne de Ferhad ile Şirin'in kavuşmalarına izin verir. Bu noktada Mehmene Banu'nun arzusunda Girard'ın bahsettiği çileciliği (Bkz. Girard, 2013, s. 132-134) görmek mümkündür. Model-mürit ilişkisinde arzuyla ilgili her belli ediş karşı tarafın da arzusunu daha da kışkırtacağından 
arzu saklanır, gösterilmez. Bu gizleme Girard tarafından nesneye ulaşmak için modelden gizlenen dinsel bir çilecilik olarak görülmüştür. 11 yıl bekleyen Mehmene Banu, Şirin'e bir defa bile Ferhad'la ilgili hislerini söylemez. Şirin bu durumu üçüncü yılın sonunda ölmek üzere olan Vezir'in ağzından öğrenir. Ve karşııklı konumlanan model ilişkisinde Şirin'in çileciliği de o gün başlar: "ŞĩiN: (...)Ben inanmadım. Fakat bir kere şüphe düştü içime... Hâlâ kurt gibi kemiriyor... Daha beteri, daha kötüsü bu ikinci şeyi işitmiş olmam, ablama gidip sana koştuğu şartı geri alması için yalvarıp yakarmama engel oldu" (Hikmet, 1987, s. 131).

Şirin ve Mehmene Banu'nu bu karşlıklı konumlanmaları bir sadist-mazoşisł ilişkisi doğurur. Girard, 'mimetik arzu'nun model-engel ilişkisinin sonuç olarak hep kölelikle sonuçlanacağını söyler. Özne, model ile yakınlaştıkça bu durum daha da belirginleşmektedir. Kölelik arzunun neden olduğu tehlikelere de sakınımsız atlama sonucunu doğurur. Bu yolla, yaratılmıs arzunun yeni boyutlarının keşfedileceği düşünülür. Ama bu ümitsiz çırpınış bir çeşit mazoşizmden kaynaklanmaktadır (Girard, 2013, s. 151-152). Şirin bu nedenle ayrilığa ve ablasının inadına direnir. Girard'a göre mazoşist 'kötü'nün zaferinin farkındadır. Ama davasını haklı görür ve savaşmayı bırakmaz. "Umutsuz olduğu ölçüde daha da 'övgüye değer' dir bu savaş" (2013, s. 157). Diğer yandan birbirlerine acı vermektedirler. Şirin güzelliğiyle olduğu kadar arzu nesnesini elde etmeye daha yakın oluşu ile, Mehmene Banu ise elinde bulundurduğu güç sayesinde bu rekabet ilişkisinin sonlanmasını engelleyerek...

Girard sadizmin de mazoşizmin diyalektik bir 'öteki' yüzü olduğunu belirtir. Arzu eden kişi kurban ya da köle olabildiği gibi işkenceci olmayı da seçebilmektedir. Bu durumda sadist özne kendi durumunu dolayımlayıcıya yansıtıp, onu da ikinci bir 'kendi' yapmaya çalışır. Bu Girard'ın da söylediği gibi (2013, s. 155) bir çeşit kurbancellat oyunudur. Mehmene Banu dolayımlayıcısı-modeli olarak Şirin'i hep yakınında tutmaktadır. Onun sayesinde devam eden arzusunu, onun nesne üzerinde sahip olduğu devamlı hale gelmiş ve uzaklaşamayan hak ile güçlendirmektedir. Benzer bir şeyi Şirin'in de yaptığı dikkati çeker: O da ne sarayı terk etmekte ne de ablası ile konuşmaktadır. Kendi arzusunun kaynağı olarak sadist-mazoşist bir tutumla bir çeşit işkence gören ve işkence gördüren rolüne bürünür (Bkz. Girard, 2013, s. 154-155).

Tüm bu süreç boyunca şehirdeki susuzluğun neden olduğu salgın devam 


\section{$\operatorname{arts}=$}

etmektedir. Salgın ve ölümlerin haberi değil sesleri gelmektedir. Mehmene Banu'nun Ferhad ile konuştuğu 2. perde 2. sahnede (Hikmet, 1987, s. 115) saraya ulaşan sesler salgından yakını ölenlerin sesleridir. Bu, şiddet mekanizmasının ikame kurbanı bulup oybirliğine dayalı şiddeti yaratamadığı bir toplumun yıkımıdır.

Metnin bir diğer 'mimetik arzu' izleği 2. sahnede gördüğümüz Ferhad'ın nakkaşlığı çevresinde örgütlenmiş olan ilişkidir. Bu sahnede Şirin için yapılan köşkün nakışları işlenmektedir. Sahnede Ferhad, Ferhad'ın babası Behzad, Ustabaşı ve Dadı'nın oğlu Şerif vardır. Nakkaşlık bu noktada bir 'arzu nesnesi' olarak ortaya çıkar. Ferhad nakkaşlıktaki ustalığı ve hüneri ile diğerleri için bir model işlevi görmektedir. Şerif, Ferhad'ın işaret ettiği nakkaşlığa bir karasevda şeklinde tutulmuştur. Dadı oğlu Şerif'in durumunu bir başka sahnede şöyle ifade etmektedir: " (...) Seninkisi nakkaşlık değil, karasevda... Dilesen vezir olurdun..." (Hikmet, 1987, s. 92).

Oyun içinde Şerif'in nesne olarak gerçekten nakkaş ustalığına ulaşmayı asında unuttuğunu ve sadece Ferhad'ı bir dolayımlayıcı olarak alt etmeye çalıştığını görürüz. Ferhad'ın yaptıklarını küçümser, o baygın düştüğü anda su vermekte tereddüt eder. Şerif'in Ferhad'a karşı şiddet döngüsünün eşiğinde dolaşan düşüncelerini okumak için repliklerine bakmak yeterlidir. Ferhad dört gün dört gece çalışıp nakış işlerken uyuyakaldığında Şerif rakibinden kurtulmak için dileğini dillendirir: "Öldü belki... Kımıldamıyor zaten... Gebersin" (Hikmet, 1987, s. 80).

Ferhad'ın yarattığı nesnedeki (nakkaşlık-ustalık) itibar bir kartopu etkisini de çoktan doğurmuştur. Şerif'in sözleri ile başlayan aşağıdaki bölüm bu durumu özetler:

ŞERIF: Kıskanmıyor musun?

USTABAŞI: Ben mi? Kimi?

ŞERIF: Ferhad'ı.

USTABAŞI: Ne yalan söyleyeyim, genç olsam hasedimden çatlardım. Hani, doğrusu, şimdi de yüreğimin bir yanı gülüyorsa, bir yanı ince ince sızlıyor. Babası bile içerlemiştir biraz... Değil mi, Behzad Usta?

BEHZAD: Bilmem. (Şerif'e seslenir.) Sen nasıl buldun, ağam? Boyaları sahiden de benimkilerden...

ŞERIF: Senin boyaların lafı mı olur? Hele şu yeşilin yanında!...

BEHZAD: Peki, peki...(Hikmet, 1987, s. 82)

Aslında babası Behzad ve Ustabaşı da Ferhad'ı bir arzuya işaret eden model 


\section{arts $=$}

olarak görmektedirler. Onları rekabetten ve şiddet döngüsünden uzak tutan tek şey yaşlarıdır. Yenilgilerini kaçınılmaz olarak kabul etmişler ama yine de 'mimetik arzu'yla donanmış ve modelin çevresinde yer almışlardır. Bu durumun özellikle Şerif için tam bir prestij savaşına dönüştüğü, kendi varlığını ispat edebilmek için Ferhad'ı alt etmesi gerektiğini düşündüğü görülür. Ustabaşı ve Behzad'da Şerif'e Dadı ile aynı öneriyi sunarlar ama o bu ihtimali aklından bile geçirmez.

BEHZAD: Dilediğin memlekete Vali olursun... Şerif Ağa...

ŞERiF: Ben nakkaş olmak istiyorum...

USTABAŞI: Sen bilirsin... Lakin Vali olmak...

ŞERiF: Ben nakkaş olmak istiyorum... Olmuşum zaten... (Hikmet, 1987, s. 79)

Şerif sadece Ferhad ile girdiği rekabeti kazanmak istemektedir. Ferhad ile Şirin'in aşkını öğrendikten sonra annesi ile beraber kaçmalarına yardım eden de Şerif olur. Fakat bu noktada niyetini bir kez daha belli eder. Şartı boyaların sırlarını öğrenmektir:

ŞERiF: (Ferhad'a) Duydun ya, Ferhad Ağa... Yani demek isterim

Ki...

FERHAD: Bütün bunları konuşmadık mı?

ŞERiF: Bir daha konuşalım... Yarın sabah...

FERHAD: (Şerifin sözünü keserek) Yarın sabah benim odama

geleceksin, sana yeşil boyamın, yeryüzünde benden başka

kimsenin bilmediği yeşil boyamın sırını vereceğim...

ŞERiF: Lale kalemininkini de...

FERHAD: Bunu konuşmamıştık.

ŞERiF: İşte şimdi konuşuyoruz ya.

FERHAD: Peki, lale kaleminin de sırrını verecegım... Daha,

dahası yok mu, benden daha başka bir şeyler, başka bir

şeyler daha istesene...

DADI: (Şerife) Şerif'im, ah Şerif'im, aklın fikrin hep boyada, hep

kalemde... Halbuki... (Hikmet, 1987, s. 92)

Onlara kavuşmalarını sağlamak için yardım etmiyordur. Niyeti Ferhad'ın nakkaşlık sırlarını öğrenmek, onun şehirden gitmesini sağlamak ve onu alt etmektir. Bu noktada yardım niyeti bir çeşit şiddettir. Rakibini sılarını ele geçirip, nesneden uzaklaştırarak yok etmiş olacaktır.

Fakat tam da Girard'ın özne ve modelin birbirinin arzusunu körüklediği ile ilgili 


\section{arts}

görüşüne paralel bir süreç yaşanır. Şerif'in alt etmek için kaçma konusunda yardım ettiği Ferhad belki kaçarak değil ama Demirdağ'ı delme şartı sonrası dolayımlayıcımodel-engel olmaktan uzaklaşır. Bu durumda Şerif nakkaşlıkta usta olmuş olsa da arzusunu besleyen öge ortadan kalkmıştır. Bunun sonucunu oyunun sonunda açık bir şekilde görürüz. Şerif, Demirdağ'ı delen Ferhad'ın yanına belli ki zaman zaman uğramaktadır. Bu durumun onun rekabetilişkisindekizaferini canlı tutmakistemesinden kaynaklandığı düşünülebilir. Fakat Ferhad bir rakip olmaktan vazgeçmiştir. Dolayısıyla Şerif'in arzusunun kaynağı kesilir. Bu durumda dolayımlayıcının eksikliğini gidermek için bir çeşit mazoşizmin devreye girdiğini söylemek mümkündür. Şerif, Ferhad'ın aşılamaz bir dolayımlayıcı olduğunu bilmektedir, o rekabetten çekilse bile onun bir şekilde 'arzu'nun kaynağı olmasını sağlamaya çalışır. Model-tanrısını harekete geçirip kendi başarısızığına tekrar kendini döndürerek dolayımlayıcısını var edecek ve böylece arzusunu körüklemiş olacaktır ( Bkz. Girard, 2013, s. 149-154).

Oyunun 3. perde 1. sahnesinde Ferhad'ı bir kez daha ziyarete gelen Şerif yanındaki Behzad Usta'ya nakkaşlıkta kullanılabilecek yapraklar gösterir. Kendi zaferini Ferhad'ın yanında kutlamak ister ama görürüz ki rakibinin yokluğunda hâlâ Ferhad'ın ona verdiği sırlar ile zaman geçirmiştir. Ferhad ona, gösterdiği yaprakların değil başka yaprakların daha iyi sonuç vereceğini söyler. Şerif, onun yanına gelip zaferini perçinlemeye çalıştığı anda da kendi zayıflamış arzusunu görmüş olur: "ŞERIF: Bilir misin, Ferhad, nerden bileceksin ya, kendime Şerif Ağa değil, Şerif Usta dedirtmek için..." (Hikmet, 1987, s. 125).

Artık bir usta olarak anılmaktadır. Ferhad ise onun dilinde Ferhad Usta değil, Ferhad'dır. Behzad Usta, Şerif'in yanıldığını görür görmez onv ilk olarak elde ettiği ünvanı geri almakla tehdit eder. "BEHZAD: Oğlumun hakkı var, Şerif Usta... Fazla kalın kafalılık etme, yine Şerif Ağa derim ha..." (Hikmet, 1987: 126) Çünkü o da hâlâ 'mimetik arzu'nun bir parçasıdır.

'Mimetikarzu'ile donanmışikikişi, Mehmene BanuveŞerif dolayımlayıcılarından yani model-tanrılarından uzaklaşamamaktadırlar. Arzularını canlı tutacak yegâne seçenekleri budur.

Oyunun bir diğer ve oldukça dikkat çekici 'mimetik arzu'su Ferhad ve 
Demirdağ ilişkisinde görülür. Ferhad oyun içerisinde Şerif ve diğer nakkaşlar tarafından model/dolayımlayıcı, Şirin ve Mehmene Banu tarafından da nesne olarak görülmektedir. Şerif'le girdiği mücadelede rekabet, arzusunu kırbaçlayamayacak kadar düşüktür. Şirin'in elde etme konusunda da bir rakiple karşılaşmaz. Ferhad metinde sürekli bir kazanan olarak çıkar karşımıza. Onun 'mimetik arzu'su ise Demirdağ'ın delinmesi noktasında rekabete ve şiddete uzanacak bir döngüye ulaşır. Metin boyunca şehirdeki susuzluk ve daha sonra bu susuzluğun neden olduğu hastalıklar düzeltilemez bir problem olarak ortadadır. Mehmene Banu'nun babası zamanında çabalar boşa gitmiştir. Bir çok kişi Demirdağ'ı delme pahasına hayatını vermiştir. Demirdağ'ı delebilmek şehre suyun ulaştııımasını sağlayacaktır. Dolayısıyla Demirdağ'ı delebilecek kişi kurtarıcı olacaktır. Girard'ın bahsettiği tanrısal gücü kendinde toplayacaktır (Girard, 2003, s. 204).

Tanrısal gücün bir kişide somutlanması şiddetin toplum dışına atılamadığı ve kutsal ve aşkın şiddetin sağlanamadığı durumlarda ortaya çıkar. Ve rekabetin sürekliliğine, intikam döngüsünün devamına neden olur. Bir nesne olarak şehre su ulaştırmak ve insanları kurtarmak, Mehmene Banu'nun yapamadığını yapmak, Demirdağ'ı delmek çevresinde dolayımlanır. Demirdağ suyu hapsetmiştir. Demirdağ'ı alt edecek ve suyu halka ulaştıracak kişi efsanesi Ferhad'ın gözünde bir rekabe† ilişkisi başlatır. Çünkü o bir kazanan, yiğit olarak metin boyu bu rekabet ilişkilerindeki zaferleri ile özdeşleştirilir. Nakkaşlıkta ustadır, sevdiği Şirin'i alıp saraydan kaçmayı başarır, yakalandıklarında da bir yiğit gibi savaşır.

FERHAD: Teslim olmak adetimiz değildir, Sultanım.

MEHMENE BANU: Dövüştün. Sen meğer yalnız nakış yapmasını değil, dövüşmesini de bilirmişsin.

FERHAD: Bilirim, Sultanım (Hikmet, 1987, s. 115).

Tüm bu özellikleri onu, pek çok rakibin başaramadığı Demirdağ'ı delme işine yönlendirmiş olmalıdır. Mehmene Banu'nun alt edilmesi ile donanmıştır. Arzu üçgeni şöyle kurulmuştur:

Özne-Model-Nesne ---> Ferhad - Mehmene Banu ve Demirdağ'ı delmeye çalışanlar- Suyu şehre ulaştırmak: Kahramanlık (tanrılık)

Diğer yandan aynı durum şöyle de okunabilir: Ferhad yakalandıktan 


\section{arts}

sonra Mehmene Banu tarafından bir rekabet ilişkisine sürüklenir. Şirin'i elde etmek istemektedir fakat bunun için Demirdağ'ı delmelidir. Ferhad, Mehmene Banu'nun ve başka kimsenin yapamadığı bu şeyi bir dolayımlayıcı olarak görebilir. Çünkü nesnesine giden yolu emeğinin işaret etmesi gerektiğine inanmaktadır.

FERHAD: (...) Bu kadar kolay, bu kadar rahatça... Rahatçadan da başka bir şey, bu kadar...

(...) Düşün ki, Şirin, sana ulaşmak için benden hiçbir şey istenmedi (Hikmet, 1987, s. 95).

Bu nedenle Mehmene Banu'nun dağı delmesi ile ilgili teklifini hemen kabul eder. Bu anlamda 'arzu'nun metafizik bir kökene dayandığı görülebilir. Tıpkı Girard'ın da ele aldığı gibi Don Kişot'un şövalyelik arzusunun kaynağının kitaplarda yer alan Şövalye Amadis olması gibi (2013, s. 23-25) Ferhad da aşılamayan bir efsane olarak Demirdağ'ı kendine dolayımlayıcı-rakip-engel yapar. Nâzım Hikmet'in pek çok diğer şeyle birlikte Demirdağ'ı da konuşturmuş olması (1987, s. 122) bu modellikte onu da canlı bir rakip olarak görmemize daha net olanak sağlar. Demirdağ, önce kimsenin alt edemediği, suyu esir tutan olarak, sonra Şirin'e kavuşmak için Mehmene Banu tarafından gösterilen bir hedef olarak karşımıza çıkar. Bu noktada arzu üçgeninin bir diğer inşası şöyledir:

Özne-Model-Nesne ---> Ferhad - (Mehmene Banu ve verdiği görev: Demirdağ'ı aşmak - Şirin

Bu ilişkide Mehmene Banu'nun rolünü de açıklamak duruma ışık tutacaktır. Ferhad'ı elde etmeye çalışıken onu unutup Şirin'i hedef alan Mehmene Banu, Ferhad 'ı Şirin'den ayırmayı bir ceza olarak görür. Böylece Şirin'e karşı olan rekabeti kaybetmemiş olacaktır. Kendi kazanamasa da rakibinin kazanma olasılığını ortadan kaldıır. Ferhad'a da Demirdağ'ı, Şirin'e ulaşmak için bir hedef olarak bildirir. Ferhad için Mehmene Banu'nun alt edilmesinin yolu dağın delinmesinden geçer, ancak bu yolla Şirin'e ulaşacaktır. Mehmene Banu, Şirin'i ulaşılmaz kıldığı oranda Ferhad'ın onv elde etme isteğinin arttığını söylemek mümkündür.

Bu noktada oyun sonunda Mehmene Banu'nun Ferhad'ın dağı delmekten vazgeçmesi halinde Şirin'le kavuşmalarına izin vereceğini söylemesi metnin süregenel 'mimetik rekabet'inin bir sonu gibi görünmektedir. Ve özne-model-nesne ilişkisinde 
Mehmene Banu'nun uzun yıllara yayılan çatışma ortamından çekilmesi anlamına da gelir. Kuşkusuz Demirdağ'ın delinmesi bir hükümdar olarak Mehmene Banu için farklı açıdan bir yenilgi yaratacaktır. Ferhad'a bir ceza olarak ilettiği bu iş uzun zamandır yönettiği ülkenin yaşadığı sorunu çözmesi gerekenin kendisi olduğunu düşünmeyen bir hükümdarın başarısızlığıdır. Bu noktada Nâzım Hikmet'in metninde kurban olarak sürekli işaret edilen, şehirdeki krizin ve şiddet döngüsünün sorumlusu olan hükümdar Mehmene Banu 'mimetik arzu' izleğinin dışında okunabilmektedir. Kuşkusuz Ferhad'ın 11 yıl boyunca süren ve pes etmeyen kararlılığı, Demirdağ'ı bir hedef ve engel olarak Ferhad'ın önüne sunan Mehmene Banu için farklı bir düşünce açmıştır.

Öte yandan temelde yer alan mimetik rekabetler ağında finale doğru Ferhad'ın Demirdağ ile ilişkisi merkezli bir değişim göze çarpar. Bu nokłada metnin izleğinin Girardyen bir okumaya direnç göstermeye başladığı görülür. Tüm kurban basmakalıplarının Mehmene Banu'yu işaret ettiği bu toplumsal yapıda kurucu şiddet gerçekleşmediği için şiddet kısır döngüsü süreğen hale gelmiştir. Ferhad bu döngünün kırıması için Nâzım Hikmet'in toplumcu gerçekçi düşünün bir temsilcisi olarak kendini feda eden bir kurban-kahraman haline gelmeye başlar. Mehmene Banu tarafından verilen cezayı çoktan unuttuğunu söyler (Hikmet, 1987, s.133).

Ferhad, tüm yaşamını feda ederek, dağın delinmesi ve şehrin içinde bulunduğu kaostan kurtulması için çalışmaktadır. Girardyen bir bakışla Ferhad'ın dağı delme çabasında mazoşist bir yan da görülebilir. Şirin de oyunun sonunda Ferhad'ın dağ ile ilişkisini benzer bir şekilde ifade etmiştir: "Ferhad'ım bana kavuşmak için zaten eziyet çekmek istiyordu diye düşü..." (Hikmet, 1987, s. 130). Ama Ferhad onun sözünü keser ve bu düşünceyi reddeder. Bir yandan, 'mimetik rekabet' çerçevesinde okunduğunda, nasıl ki dolayımlayıcının yani ablasının yasağı Şirin'in arzusunu körüklüyorsa, Ferhad'ın da dağın, verdiği tüm mücadeleye rağmen delinmemesi ile sonuçta ulaşacağı başarı kadar yinelenen hayal kırıklığının arzusu ile de donandığı düşünülebilir. Girard böyle bir noktada rekabette oluşan sürekli başarısızlığın sonucunu şöyle ifade eder: "Yalnızca bu başarısızlık onun için gerçek bir tanrıyı, kendi girişimlerinden etkilenmeyen bir dolayımlayıcıyı ortaya çıkarabilecektir" (2013, s. 149).

Ferhad arzusunu körükleyen dolayımlayıcısı, tanrısı Demirdağ'ın çevresinden 


\section{$\operatorname{arts}=$}

bu nedenle ayrılamaz diye düşünülebilir. Ama diğer yandan ortada neredeyse bir rekabet kalmamıştır. Ferhad, Mehmene Banu tarafından işaret edilen nesneye ulaşma girişiminde Mehmene Banu'yu bir rakip olarak unutmaya başlamış ve sorunun çözümü için bir kurban-kahraman haline gelerek 'mimetik rekabet'ten bir toplum kurtarıcısına doğru bir değişim geçirmiştir. Dolayısıyla da sonucun getireceği kurtuluş (suyun şehre ulaştırılması) ve dahası kavuşma (Şirin) ile bir türlü delinemeyen dağın bir model-tanrı olarak Ferhad'ın arzusunu hep diri tutması gittikçe birbirinin içinde erimeye başlar. Ferhad'ın şu sözleri dağın çevresinde gittikçe bireysel bir arzudan toplumsal bir mücadeleye doğru evrilen görüşlerine ışık tutar: "iki iş birbirine karıştı, (...), hatta artık hangisi ağır basıyor, ağır basmak meselesi de değil, yani demek istediğim..." (Hikmet, 1987, s. 125). Artık bireysel bir arzu olarak Şirin'e ulaşmakla Demirdağ'ın delinmesinin getireceği kurtuluş bir olmuş, Demirdağ Şirin, Şirin Demirdağ haline gelmiştir.

\section{SONUÇ}

Metin boyunca yoğun olarak okunan tüm 'mimetik arzu' kökenli ve aynılığı sürekli doğuran ilişkiler bir intikam kısır döngüsü yaratmıştır. Arzen şehri kaosun ortasında yer almakta ve yıkıma sürüklenmektedir. Kurucu şiddet bir türlü gerçekleşmemektedir. Üstelik 'arzunun cehennemi mekanizması' toplumda farksızlığı öyle bir noktaya getirmiştir ki, sadece metnin olay örgüsünde yer alan durumlarda değil, Arzen şehrinin halkı arasında da yayılmaktadır. Dadı metinde süreğen hale gelmiş intikam durumunun tellallığını yapar. Olan her şeyden haberi vardır: Şehirde hastalık çıkar. Dadı şehrin bu nedenle bir gün batacağını söyler (Hikmet, 1987, s. 107). "Mimetik arzu'nun yarattığı kartopu etkisini ve bunun yarattığı şiddetin şehirdeki içselleşmiş hâlini bir örnek üzerinden açıklar:

DADI: Bak, Sultanım, sehirlilerden bir Zehra vardır, kervancı Alizade'nin kızı... Çiçek bozuğudur...Bir avuç leblebi at suratına, bir tanesi yere düşmez. Gelgelelim onun da bir endamı var. Seninkinin yanında kale alınmaz ama, Allah ona bir endam vermiş, bacaklar, memeler, bel, boyun... Babası da zengin... Delikanlılar birbirini vuruyormuş: Zehra'ya sen görücü göndereceksin, ben göndereceğim diye... (Hikmet, 1987, s. 108).

Şiddetin topluluk dışına yansıtılması şöyle dursun dalga dalga yayılan mimetik rekabetler saraydan şehre ve oradan Demirdağ'a kadar uzanmaktadır. 
Ama Nâzım Hikmet'in metne ördüğü toplumcu gerçekçi çizgi oyun sonunda Girardyen bir okumaya karşıt bir yapı ortaya çıkarmıştır. Ferhad oyunun sonunda 'mimetik rekabet' ağının dışına bir adım atarak toplumsal kurtuluşa dönük bir feda kültürünün temsilcisi olarak belirmiştir. Aşkının önüne engel çeken bir hükümdar olarak Mehmene Banu'yu kendisine dolayımlayıcı almaktan uzaklaşmış ve dağın delinmesi, suyun şehre ulaşması ve şehirdeki krizin, salgının son bulması için bir kurbankahraman haline gelmeye başlamıştır. Gerçek bir suçlu olmasına ve tüm kurban basmakalıplarını taşımasına rağmen bir türlü kurucu şiddetle cezalandırılmayan Mehmene Banu yerine, kendi hayatını bu kurtuluş için adamıştır. Mimetik rebaketler ağının yarattığı kriz ortamı ile Girard'ın tasarımına uymaya devam eden oyunda Ferhad'ın bilinçli olarak kurban-kahraman konumuna geçişi 'mimetik arzu'ya koşu† bir yapının ortaya çıkmasını sağlamışłır. İki izlek de farklı özellikleri ile oyun sonunda görünmektedir: Ya Ferhad kendini feda edişi ile kurtuluşu getirecektir ya da Girard'ın şiddet kısır döngüsü, farksızlığı ortadan kaldıracak ve kurucu şiddeti gerçekleştirecek bir kitlenin hareketine kadar sürecek gibi görünmektedir.

\section{KAYNAKÇA}

Bailie, G. (1995). Violence Unveiled: Humanity At The Crossroads. New York: Crossroad.

Fleming, C. (2014). Mimesis, Violence, and the Sacred: An Overview of the Thought of Rene Girard. S.Cowdell, C. Fleming, J. Hodge (Ed.), Violence, Desire, And The Sacred (s. 1-13). Broadway/Bedford: Bloomsbury.

Girard, R. (1978). Interview with Rene Girard. Diacritics, 8, 1, Special Issue on the Work of Rene Girard, 31-54.

Girard, R. (1991). Theatre of Envy: William Shakespeare. Indiana: St. Augustine's.

Girard, R. (2003). Şiddet ve Kutsal (Çev. N. Alpay). İstanbul: Kanat Kitap.

Girard, R. (2005). Günah Keçisi (Çev. I. Ergüden). İstanbul: Kanat Kitap.

Girard, R. (2013). Romantik Yalan ve Romansal Hakikat: Edebi Yapıda Ben ve Öteki (Çev. A. E. İldem). İstanbul: Metis.

Girard, R. (2018). Dünyanın Kuruluşundan Beri Gizli Kalmış Sırlar (Çev. A. 
Berktay). İstanbul: Alfa.

Hikmet, N. (1987). Ferhad ile Şirin (Toplu Oyunları 2). İstanbul: Adam.

Seyidoğlu, B. (2002). Ferhad ile Şirin. A.Ü. Türkiyat Araştırmaları Enstitüsü Dergisi, 19, 133-135.

Timurtaş, F. K. (1959). Türk Edebiyatında Hüsrev ü Şirin ve Ferhad ü Şirin Hikayesi. İstanbul Üniversitesi Edebiyat Fakültesi TDE Dergisi, 9 (12), 65-88. 